\title{
Distribution of aquaporins in the nasal passage of Octodon degus, a South-American desert rodent and its implications for water conservation
}

\author{
Distribución de acuaporinas en los pasajes nasales de Octodon degus, un roedor de am- \\ bientes desérticos sudamericanos: implicaciones en la conservación de agua
}

\author{
PEDRO GALLARDO $^{1 *}$, SOFÍA HERRERA ${ }^{1}$, KARIN SAFFER $^{2} \&$ FRANCISCO BOZINOVIC $^{2}$ \\ ${ }^{1}$ Departamento de Fisiología. Facultad de Ciencias Biológicas, Pontificia Universidad Católica de Chile, Santiago, \\ CP 6513677, Chile \\ ${ }^{2}$ Center for Advanced Studies in Ecology and Biodiversity and Departamento de Ecología. Facultad de Ciencias \\ Biológicas, Pontificia Universidad Católica de Chile CP 6513677, Santiago Chile \\ *e-mail for correspondence: pgallardo@bio.puc.cl
}

\begin{abstract}
Rodents from arid and semiarid environments live under conditions where the spatial and temporal availability of water is limited. Octodon degus is a South-American desert-dwelling rodent inhabiting arid and semiarid habitats of central and northern Chile. Its survival depends on morphological, physiological and behavioral adaptations that allow water conservation. This rodent has a high urine concentrating ability, high capacity of fecal dehydration and low evaporative water loss, related to the ability of the nasal passages to condense water from the exhaled air; this water must be absorbed in order to avoid its accumulation in the nasal passages and potential loss through the nostrils. We hypothesize that aquaporins (AQPs) might be present in the nasal mucosa; therefore, we studied the distribution of AQP-1, AQP-2, AQP-3 and AQP-4 through immunocytochemistry. Intense AQP-1 labeling was observed throughout the subepithelial vascular network; no AQP-1 immunoreactivity was detected in olfactory and non-olfactory epithelial cells. No signal was detected for AQP-2 and 4. AQP-3 distribution was restricted to the surface non-olfactory epithelial cells lining the turbinates in narrow passages and blind spaces. Therefore, AQP-1 and AQP-3 coincided at the level of the turbinates, although in different cell types which suggest a pathway for water removal from the nasal surface first through AQP-3 in non-olfactory epithelial cells and then into the capillary lumen through AQP-1.
\end{abstract}

Key words: aquaporin, nasal passage, desert rodent.

\section{RESUMEN}

Los roedores de ambientes áridos y semiáridos viven bajo una disponibilidad limitada de agua tanto espacial como temporal. Octodon degus es un roedor sudamericano que habita ambientes áridos y semiáridos del norte y zona central de Chile. Su supervivencia depende de adaptaciones morfológicas, fisiológicas y conductuales que permiten optimizar la conservación de agua. Este tiene una alta capacidad de concentración urinaria y de deshidratación de la fecas además de una baja tasa de evaporación pulmocutánea, relacionada con la capacidad de los pasajes nasales para condensar agua contenida en el aire espirado; el agua condensada debe ser absorbida en orden de evitar su acumulación y potencial pérdida por las fosas nasales. Nuestra hipótesis es que el epitelio de los pasajes nasales expresaría acuaporinas (AQPs) que podrían servir como una vía rápida de absorción del agua condensada. Se estudió la distribución de AQP-1, AQP-2, AQP-3 y AQP-4 mediante inmunocitoquímica en cortes provenientes de animales controles y sometidos a un periodo de restricción acuosa. Se detectó abundante inmunorreactividad para AQP-1 en la red vascular subepitelial, no se detectó expresión de AQP-1 en el epitelio de los pasajes nasales. No se detectó ni AQP-2 ni AQP-4 en el mismo epitelio. Se detectó inmunorreactividad para AQP-3 en el epitelio no olfatorio que recubre los turbinales en pasajes nasales estrechos y ciegos. No se evidenciaron cambios en la abundancia de inmunorreactividad para AQP-3 entre ambos grupos. La inmunorreactividad para AQP-1 subepitelial y para AQP-3 epitelial coincide a nivel de los turbinales, aunque en diferentes tipos celulares; ello sugiere que estas acuaporinas podrían servir como una vía para la absorción de agua desde la superficie de los pasajes nasales, vía AQP-3 hacia los capilares subepiteliales a través de AQP-1.

Palabras clave: acuaporinas, pasaje nasal, roedores de ambientes áridos y semiáridos. 


\section{INTRODUCTION}

Animals have a wide range of physiological responses: from immediate to acclimation (during acute and chronic exposures, respectively), to ontogenetic (developmental), and up to several generations (evolutionary adaptation). The long as well as short-term environmental tuning of the physiology of an organism is often hypothesized to be responsible for allowing an organism to adjust to changing biotic and abiotic conditions. This is well-exemplified by desert-dwelling rodents for whom maintaining water homeostasis is a significant challenge (Walsberg 2000). Indeed, desert-dwelling rodents are continuously faced with the challenge of maintaining a positive water balance despite the temporal and spatial limited availability of free water (Degen 1997).

According to Bozinovic \& Gallardo (2006), South American xeric habitats have existed since the late Tertiary. Several authors have pointed out that South American desert rodents lack physiological specializations for energy and water conservation, postulating that their success is essentially due to behavioural and ecological strategies. Nevertheless, it has been noted that such a lack of physiological adaptations may, to some extent, be more apparent than real, because (comparatively) only a small amount of studies have been conducted in South American desert environments (McNab 1982). Recently, Bozinovic \& Gallardo (2006) reviewed current information on this topic and concluded that South American desert rodents possess structural as well as physiological systems for water conservation, which are as remarkable as those found in "classical" rodents inhabiting other desert areas of the world.

Among many South American desert rodent species, the degus (Octodon degus) exhibits remarkable features allowing water conservation such as a high urine-concentrating ability and high degree of fecal dehydration. In addition this species has also a low evaporative water loss, which had been related to its ability to conserve water in the nasal passage (Cortes et al. 1988, Cortes et al. 1990). This mechanism is intimately linked to the complex morphology of the nasal cavities of desert rodents, composed by narrow passages and blind ends formed by multiple convolutions of the turbinates. The water-sparing mechanism at this level is related to the heat countercurrent exchange mechanism that allows the condensation of water in the exhaled air (Schmidt-Nielsen et al. 1951). There is scarce information concerning the function of the nasal passages in desert rodents; however, in the degus it had been demonstrated that the nasal passages allow the conservation of near $50 \%$ of the water contained in each exhalation (Cortés et al. 1990).

Aquaporins (AQPs) are a family of membrane integral proteins, they constitute the major and fast pathway for osmotic-driven transmembrane water transport (Agre et al. 1993); they play an important role in transepithelial water absorption, which is the common process to all the water-sparing mechanisms above mentioned. AQP-2 and AQP3 are important in the vasopressin-sensitive water reabsorption in collecting ducts; AQP-1 is a key element in the constitutive water reabsorption in proximal tubules and thin descending limbs of the mammalian nephron (Nielsen et al. 2002). AQP-1 is important in water absorption and fecal dehydration in the distal colon of the degus (Gallardo et al. 2002), also changes in the protein level of AQP-2 plays an important role in seasonal adaptation of the degus to free water availability (Bozinovic et al. 2003). There is little information about the distribution of aquaporins in the nasal mucosa of desert rodents. In the nasal mucosa of the white rat, abundant AQP-1 signal was detected in subepithelial blood vessels and AQP-3 in the basolateral membranes of epithelial cells lining the nasal conchus (Nielsen et al. 1997). If the condensation of water in the nasal cavities is a water-sparing mechanism, therefore water molecules must be absorbed at some point in the passage in order to avoid accumulation and potential loss through the nostrils. We hypothesize that members of the aquaporin family might be expressed both in nasal mucosa and subepithelial blood vessels, which attempt to provide the molecular basis for the "SchmidtNielsen camel's nose" classic physiological model of water economy and regulation among desert mammals. 


\section{MATERIAL AND METHODS}

\section{Animals}

This study was carried out in adult male degus $(180-200 \mathrm{~g})$. All experiments were done according to international regulations for animal care and were approved by the Committee of Animal Bioethics of the Facultad de Ciencias Biológicas, Pontificia Universidad Católica de Chile. Before the experiments, the animals were maintained in individual cages with food and water supplied ad libitum. Food was composed of dried seeds complemented with dried alfalfa pellets. The animals were divided in two groups: a control group $(\mathrm{n}=5)$ received food and water ad libitum for 10 days; the experimental group $(n=5)$ received food ad libitum and were submitted to a water restriction period of 10 days without drinking water. The animals were anesthetized with a pentobarbital sodium (60 $\left.\mathrm{mg} \mathrm{kg} \mathrm{ip}^{-1}\right)$. Plasma and urine osmolality were measured in an osmometer (Advanced Instruments) by the freezing point depression method. Animals were sacrificed with a pentobarbital sodium overdose.

\section{Tissue and immunocytochemistry}

Both nasal cavities were removed surgically from the rest of the head and washed in ice-cold phosphate saline. Adjacent bone and cartilage tissues were also removed. The tissue was decalcified by immersion in $10 \%(\mathrm{w} / \mathrm{v})$ EDTA solution at $4{ }^{\circ} \mathrm{C}$, according to the method described elsewhere (Alers et al. 1999). Fixation and embedding of decalcified tissue was done according to the procedure described previously (Vio et al. 1997). Immunolocalization of aquaporins was carried out using polyclonal antibodies against aquaporins 1, 2, 3 and 4 (all from Upstate Biotechnology, except aquaporin-2 antibody, gently provided by Dr Mark Knepper, NHLBI, NIH). Immunocytochemistry procedure was described elsewhere (Gallardo et al. 2002). Briefly, the tissue sections were blocked for $1 \mathrm{~h}$ and then incubated overnight at $25{ }^{\circ} \mathrm{C}$ with the primary antibody (1:300 dilution). Immunoreactive sites were revealed using biotinylated swine-antirabbit IgG (Dako), followed by streptoavidin-conjugated horseradish peroxidase; the chromogen used was 3.3'diaminobezidine in the presence of hydrogen peroxide (Dako Liquid DAB plus kit, Dako). Tissue sections were observed and photographed on a Nikon Optiphot microscope.

\section{RESULTS}

In control degus, plasma and urine osmolality was $288 \pm 12$ and $2,000 \pm 125 \mathrm{mOsm} \mathrm{kg}^{-1} \mathrm{H}_{2} \mathrm{O}$, respectively; dehydration increased both plasma and urine osmolality $(300 \pm 16$ and 4,328 \pm 194 mOsm kg-1 $\mathrm{H}_{2} \mathrm{O}$, respectively).

The distal end of the nasal cavity of the degus is composed by narrow tortuous passages and blind ends formed by the convolutions of the turbinates. The nasal septum is lined by an olfactory epithelium while the turbinates and other areas are lined by squamous nonolfactory epithelium. Immunoperoxidase signal for AQP-1 was very abundant in the subepithelial vascular network throughout the entire nasal mucosa including nasal septum and turbinates (Fig. 1A and 1B); ciliated, squamous and glandular epithelial cells lacked immunolabeling for AQP-1 (Fig. 1A, 1B). No immunoreactivity for AQP-2 or AQP-4 was detected in the nasal mucosa (not shown). AQP-3 immunoreactivity was localized to some areas of the nasal mucosa, especially the epithelium lining the turbinates and blind ends (Fig. 2A); the AQP-3 positive cells were nonolfactory epithelial cells lining the surface while more basal cells has more weak or even absent immunolabeling for AQP-3 (Fig. 2B), also no immunoperoxidase signal was observed in epithelial glandular cells (Fig. 2C). Water restriction did not increase the immunoperoxidase signal compared to the control condition (Fig. 3A and 3B). Aquaporins 1 and 3 colocalized specific areas in the turbinates (Fig. 4A and 4B), which are most likely to be the tip; AQP-3 in the surface epithelial cells and AQP-1 in endothelial cells of the vascular network.

\section{DISCUSSION}

The response of rodents to unproductive desert environments and water deficits has been intensively investigated in many deserts of the world. However, current understanding of the 
cellular, systemic and organismal physiology of water economy relies heavily on short-term, laboratory-oriented experiments, which usually focus on responses at isolated levels of biological organization. The pioneer work of Schmidt-Nielsen (1979) demonstrated that some desert species, such as Perognathus sp. and Dipodomys sp., can maintain a positive water balance without water intake. These authors also demonstrated, for a few xeric species of rodents, that the main mechanisms of water input and output are metabolic water production and evaporative water loss explaining their survival capabilities during water shortage.

The mammalian nasal cavity is a complex structure, the ethmo and nasoturbinates form blind recesses while the maxilloturbinates are formed by complex folded and scrolled structures (8). In particular the maxilloturbinates are associated with an air-conditioning function; however in rodents from arid and semiarid environments like Dipodomys, these structures play an important role in the reduction respiratory water loss (Degen 1997). The evidence for a physiological role of the nasal passages in water conservation of SouthAmerican desert rodents is scarce. One study carried out in O.degus and other rodent species from desert habitats of north and central Chile showed that among these species, the degus had the lowest value of evaporative water loss. In tracheotomized animals this value was significantly increased to double and could not be accounted as an anesthetic effect, since evaporative water loss was statistically similar in control and anesthetized animals. Therefore, the nasal passages of $O$.degus retain almost $50 \%$ of the water contained in the exhaled air. The anatomy of the nasal passages of $O$. degus is consistent with a site of water recovery and conform the general pattern of complexity described above (Cortes et al. 1990).

The role of aquaporins as water transporters in the nephron and other epithelia of laboratory animals had been extensively studied (Agre et al. 1993, Nielsen et al. 2002); the distribution of aquaporins in respiratory surfaces of the rat had been documented (Nielsen et al. 1997). However, little attention has been paid to the study of aquaporins in epithelial tissues of desert rodents. Here we demonstrate that the nasal mucosa of a desert rodent is endowed with aquaporins that are probably involved in the absorption of condensed water. Water absorption in the nasal mucosa seems to be mediated by aquaporin water channels that allow for whole organism water conservation (reducing evaporative water loss) and, hence, increasing survival and colonization in desert habitats.
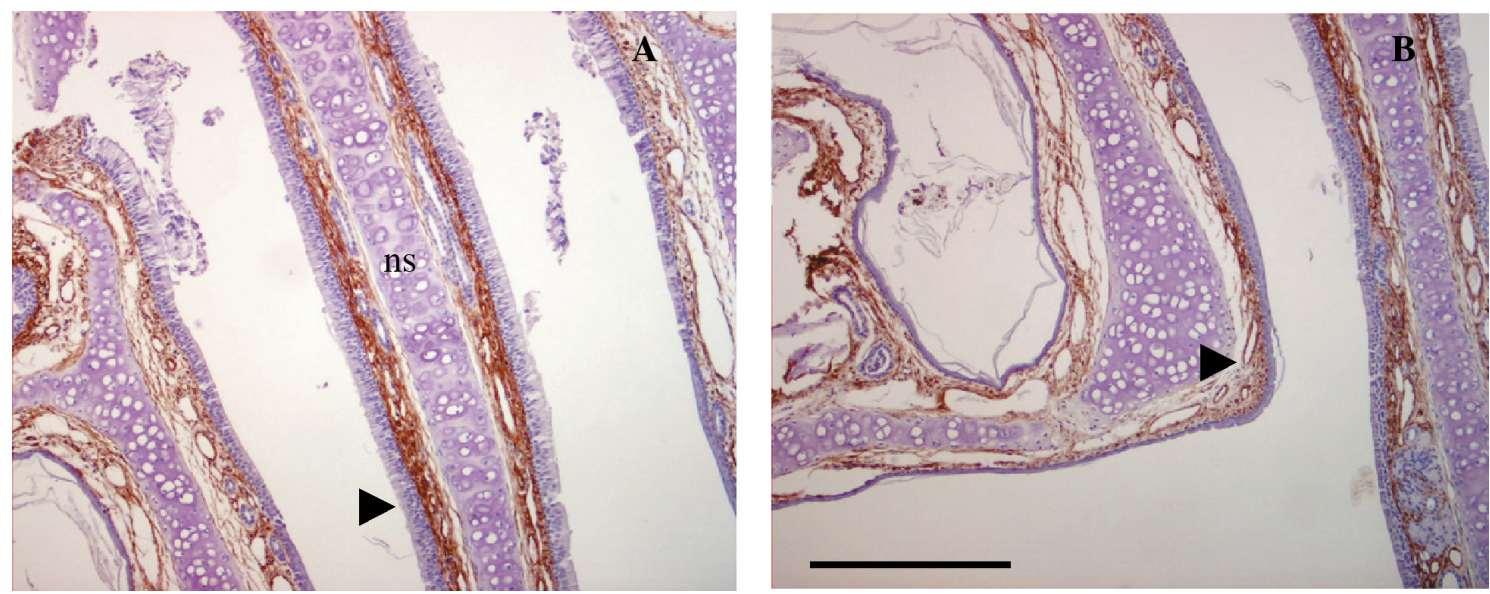

Fig. 1: AQP-1 in the nasal mucosa of O. degus. (A) Immunoreactivity for AQP-1 in the vascular network (arrowhead) associated with the olfactory epithelium; (B) AQP-1 immunoperoxidase signal in the subepithelial vascular network (arrowhead) at the level of the turbinate; (ns: nasal septum). Calibration bar: $200 \mathrm{~mm}$ for (A) and (B).

AQP-1 en la mucosa nasal de $O$. degus. (A) Inmunorreactividad para AQP-1 en la red vascular (cabeza de flecha) asociada al epitelio olfatorio; (B) señal de inmunoperoxidasa para AQP-1 en la red vascular subepitelial (cabeza de flecha) a nivel de los turbinales; (ns: septo nasal). Barra de calibración: 200 mm para (A) y (B). 

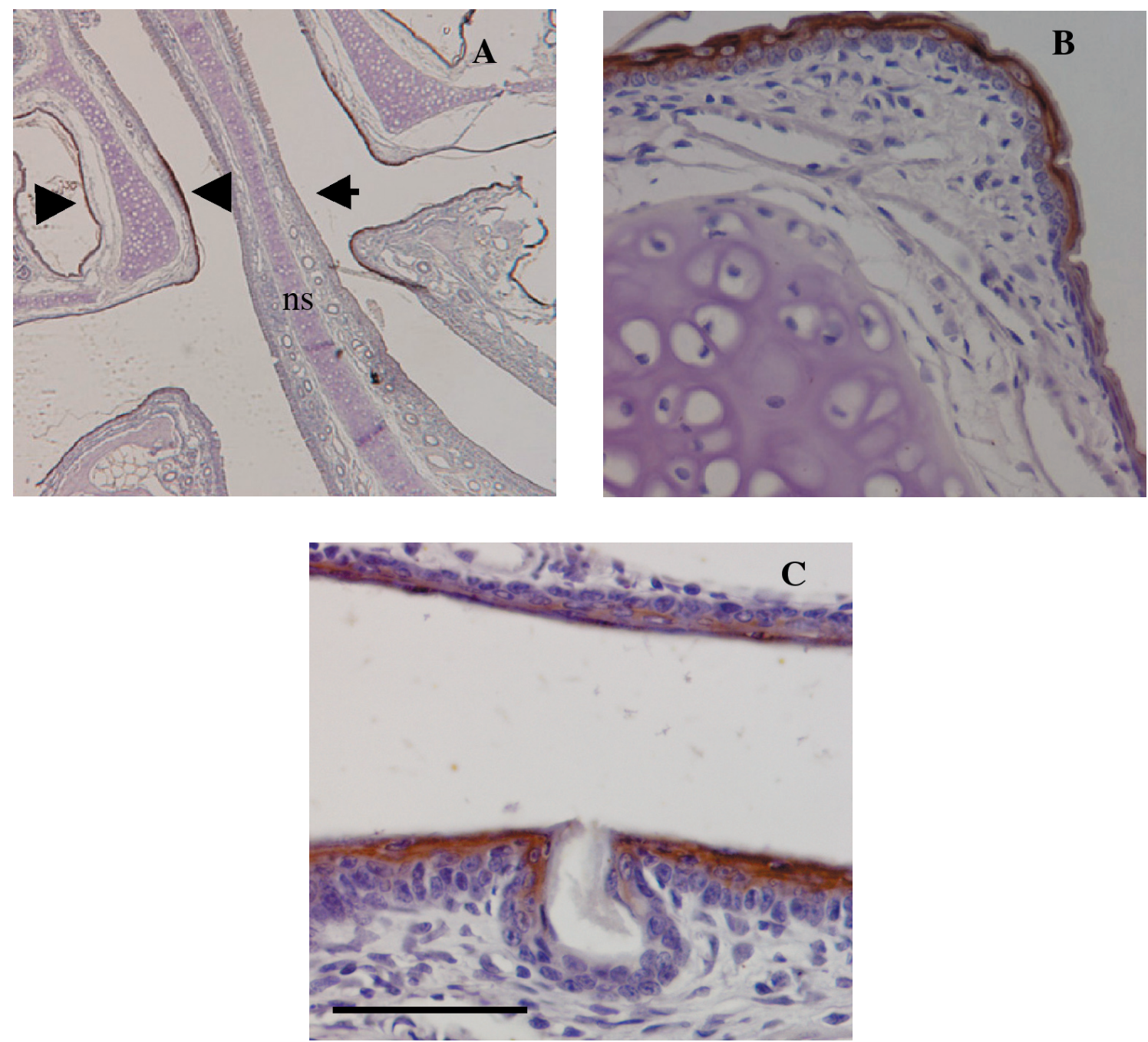

Fig. 2: Immunolocalization of AQP-3 in the nasal mucosa of the degus. (A) low magnification of the nasal passage showing AQP-3 immunoperoxidase signal in the epithelium lining the turbinate and blind ends (arrowheads), but not in the olfactory epithelium (arrow); (B) higher magnification of a turbinate tip showing non-olfactory cells intensely labeled for AQP-3; (C) AQP-3 labeling is not present in epithelial glandular cells; (ns: nasal septum). Calibration bars: (A) $500 \mathrm{~mm}$; (B) and (C) $50 \mathrm{~mm}$.

Inmunolocalización de AQP-3 en la mucosa nasal del degus. (A) Microfotografía a bajo aumento del pasaje nasal mostrando la señal de inmunoperoxidasa para AQP-3 en el epitelio que reviste los turbinales y pasajes ciegos (cabezas de flecha), pero no en el epitelio olfatorio (flecha). (B) imagen de la punta de un turbinal mostrando células no olfatorias intensamente marcadas para AQP-3; (C) marcaje para AQP-3 está ausente en células epiteliales glandulares (flecha); (ns: nasal septum). Barras de calibración: (A) $500 \mathrm{~mm}$; (B) y (C) $50 \mathrm{~mm}$.

AQP-1 immunoreactivity was localized to the subepithelial vascular network throughout the entire nasal mucosa; a similar localization had been described in the rat (Nielsen et al. 1997). The vascular network plays an essential role in the heat exchange mechanism that cools the air exhaled from the lungs (SchmidtNielsen \& Schmidt-Nielsen 1951, Schmidt-
Nielsen 1979). AQP-2 is a vasopressin regulated water channel (Nielsen et al. 2002); no immunoreactivity for AQP-2 was found in the mucosa, suggesting that water transport may not under the control of vasopressin; such a conclusion is based in the fact that AQP-2 is the only water channel whose regulation by vasopressin has been clearly demonstrated 

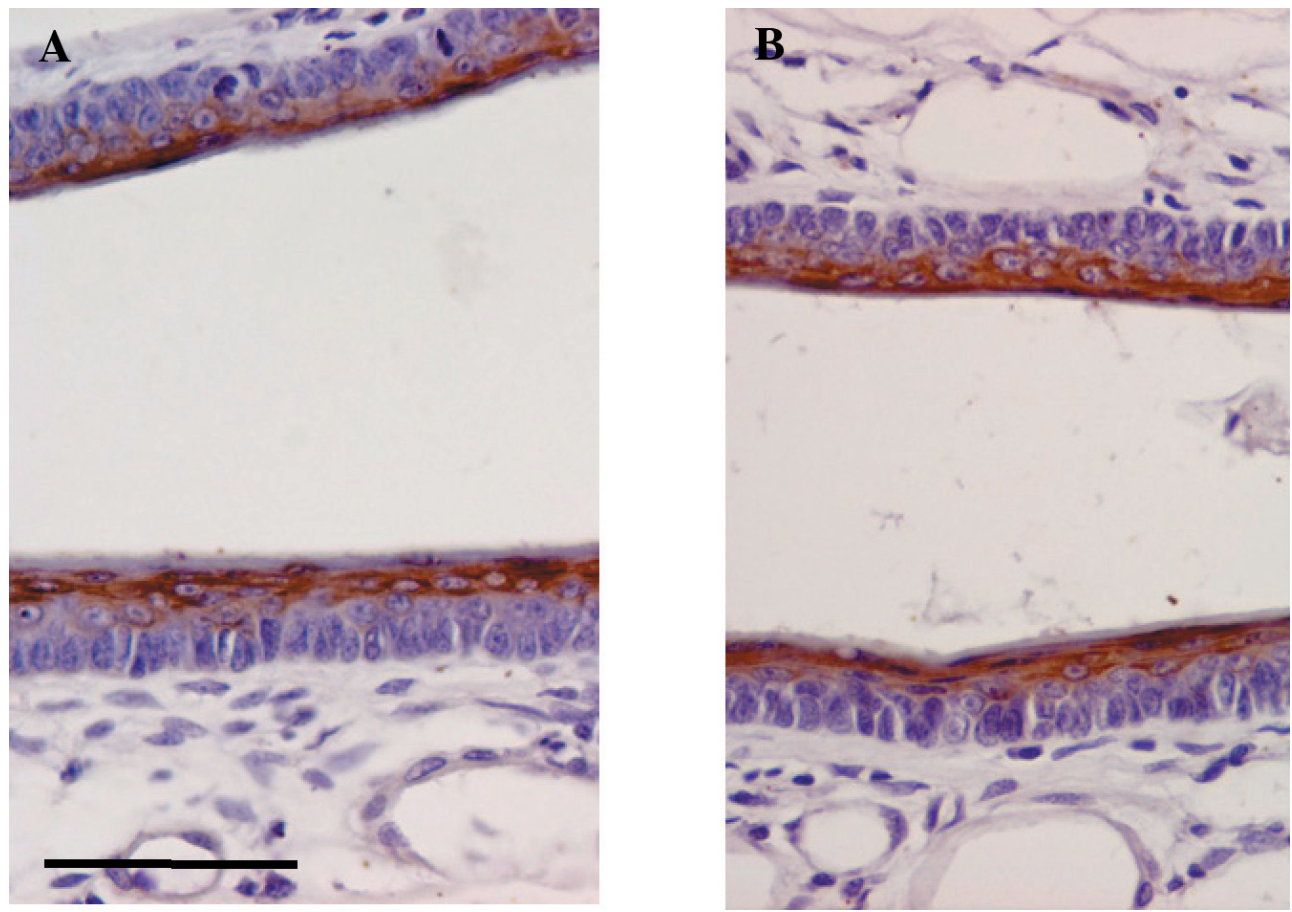

Fig. 3: Lack of effect of water restriction on AQP-3 immunoreactivity. (A) section of a nasal passage from a control animal showing the epithelial borders lining a narrow passage; (B) similar section from a water-restricted animal. Calibration bar: $50 \mathrm{~mm}$ for (A) and (B).

Ausencia de efecto de la restricción de agua en la inmunorreactividad de AQP-3. (A) Sección de un pasaje nasal de un animal control mostrando el epitelio que reviste un pasaje estrecho; (B) sección similar de un animal sometido a un periodo de restricción de agua. Barra de calibración: $50 \mathrm{~mm}$ para (A) y (B).

(Nielsen et al. 2002). No immunolabeling was also found for AQP-4. AQP-3 showed a very specific pattern of expression, AQP-3 positive cells were localized in the blind and convoluted portions of the turbinates and corresponded to non-olfactory squamous cells forming the nasal mucosa at these sites. This particular localization of AQP-3 suggests that this water channel might be involved in water recovery. Dehydration did not increase the immunoperoxidase signal for AQP-3 in the nasal epithelium, suggesting that in this epithelium the abundance of this aquaporin might not be upregulated by dehydration. In the rat kidney, it has been shown that AQP-3 is regulated by vasopressin, although the intracellular signaling pathway is still unclear (Nielsen et al. 2002).

Figure $4 \mathrm{C}$ shows that there is a conspicuous combination of aquaporins at the level of the turbinates: AQP-1 is localized in the vascular network of the lamina propria, while the most superficial epithelial cells of the stratified squamous epithelium are endowed with AQP-3. Therefore, it is possible that the following absorptive pathway may exist: water is transported through AQP-3, expressed in the squamous epithelium, from the lumen to the interstitial space and then enter the subepithelial vascular network through AQP-1. Moreover, there is evidence that the maxilloturbinates are associated with the recovery of water by desert mammals; during inhalation water evaporates from the nasal surfaces and cools the surrounding tissue; as it passes through the convoluted tubes of the maxilloturbinates, the exhaled air that comes saturated at lung temperature is cooled and condenses in the nasal mucosa (Degen 1997). Our results identify a likely molecular basis for a known physiological strategy in desert rodents which is the conservation of water under limited availability 

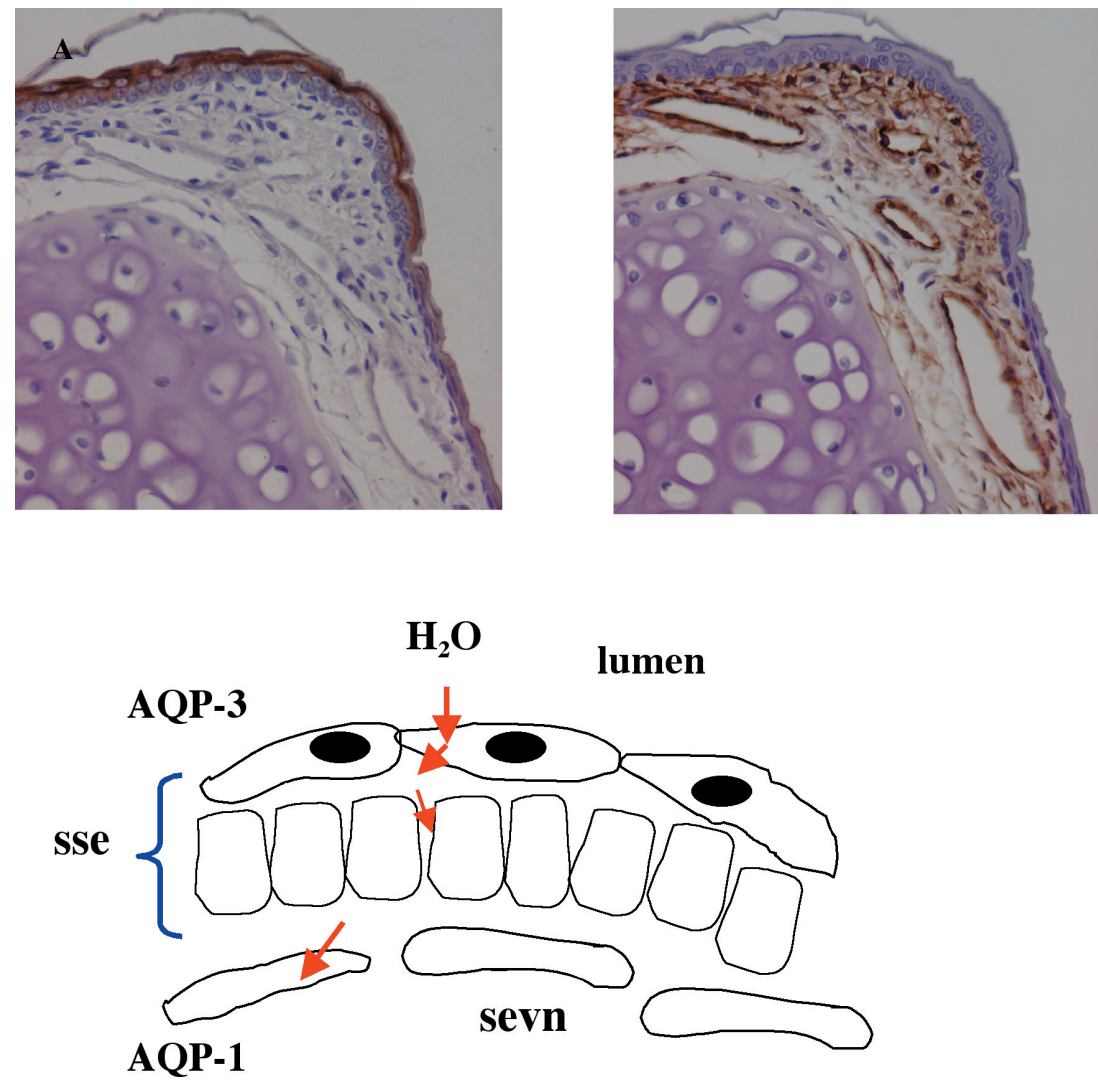

\section{Water flux}

B

Fig. 4: Possible pathway of water recovery in the nasal mucosa of $O$. degus. At the level of the turbinates, water might be transported from the surface through AQP-3 bearing-cells (A); in the lamina propria, water enters the capillary network through endothelial AQP-1 (B). (C) Cartoon of the possible pathway for water absorption in the turbinate epithelium, first though AQP-3 expressed in the stratified squamous epithelial cells (sse) and then through AQP-1 expressed in endothelial cells of the subepitelial vascular network (sevn). Calibration bar: $50 \mathrm{~mm}$ for (A) and (B).

Posible vía de paso de agua en la mucosa nasal de $O$. degus. A nivel de los turbinales, el agua podría ser transportada desde la superficie a través de células epiteliales que expresan AQP-3 (A); en la lámina propria, el agua entraría a la red capilar subepitelial a través de AQP-1 (B). (C) Esquema mostrando la posible vía de absorción de agua en el epitelio de turbinales, primero a través de AQP-3, expresada en el epitelio escamoso estratificado (sse), y luego mediante AQP-1 presente en las células endoteliales de la red vascular subepitelial (sevn). Barra de calibración: 50 mm para (A) y (B).

in space and time. In this case, as in the kidney and distal colon, the water sparing mechanism is intimately related to transepithelial water transport and to aquaporin water channel expression. The finding of this particular distribution of AQP-3 in the turbinates plus the abundant vascular network endowed with AQP1 is consistent with the physiological data suggesting a role of the nasal passages of $O$. degus in water recovery.
An intriguing point is the origin of the osmotic gradient necessary to drive water absorption. One possibility is that the water molecules condensed in the surface of the turbinates forms a hypotonic solution, and then water will be absorbed along the osmotic gradient generated between this solution and the interstitial fluid. A second mechanism will the generation of an osmotic gradient through transepithelial ion transport, most likely $\mathrm{Na}^{+}$, 
however little is known about the ion transport mechanism that operates in the non respiratory epithelium lining the turbinates.

Therefore, it is likely that the intricate architecture of the nasal passage of $O$. degus plus the distribution of aquaporin water channels in the vascular network and epithelial cells are key factors in the water-sparing mechanism that takes place in the nasal passage. Further studies are required to address whether, in the context of water transport, the nasal epithelium is an example of phenotypic flexibility.

\section{ACKNOWLEDGEMENTS}

Funded by FONDAP 1501-0001 (Program 1) to FB.

\section{LITERATURE CITED}

AGRE P, G PRESTON, B SMITH, JS JUNG, S RAINA, C MOON, W GUGGINO \& S NIELSEN (1993) Aquaporin CHIP: the archetypal molecular water channel. American Journal of Physiology Renal Fluid Electrolyte Physiology 265: 463- 476.

ALERS JC, PJ KRIJTENBURG, KJ VISSERS \& H VAN DEKKEN (1999) Effect of bone decalcification procedures on DNA in situ hybridization and comparative genomic hybridization: EDTA is highly preferable to a routinely used acid decalcifier. Journal Hystochemistry Cytochemistry 47: 703-709.

BOZINOVIC F \& P GALLARDO (2006) The water economy of South American desert rodents: from integrative to molecular physiological ecology. Comparative Biochemistry \& Physiology 142 C: 163-172.

BOZINOVIC F, P GALLARDO, GH VISSER \& A CORTÉS (2003) Seasonal acclimatization in water flux rate, urine osmolality and kidney water channels in free living degus: molecular mechanisms, physiological processes and ecological implications. Journal of Experimental Biology 206: 2959-2966.

CORTÉS A, M ROSENMAN \& C BÁEZ (1990) Función del riñón y del pasaje nasal en la conservación del agua corporal en roedores simpatridos de Chile central. Revista Chilena de Historia Natural 63:279. 291.

CORTÉS A, C ZULETA \& M ROSENMAN (1988) Comparative water economy of sympatric rodents in a Chilean semi-arid habitat. Comparative Biochemistry and Physiology 91A: 711-714.

DEGEN AA (1997) Water requirements and water balance. Ecophysiology of small desert rodents. SpringerVerlag, Berlin, Germany.

GALLARDO P, N OLEA \& FV SEPULVEDA (2002) Distribution of aquaporins in the colon of Octodon degus, a South American desert rodent. American Journal of Physiology Regulatory Integrative Comparative Physiology 283: 779- 788.

HILLENIUS WH (1992) The evolution of nasal turbinates and mammalian endothermy. Paleobiology 18: 17 29.

MC NAB BK (1982) The physiological ecology of South American mammals. In: Mares MA \& $\mathrm{HH}$ Genoways (eds) Mammalian biology in South America: 167-185. Pymatuning Laboratory of Ecology, Pittsburg, Pennsylvania, USA.

NIELSEN S, LS KING, B MOSNTER \& P AGRE (1997) Aquaporins in complex tissues II. Subcellular distribution in respiratory and glandular tissues of rat. American Journal of Physiology Cell Physiology 273: 1549-1561.

NIELSEN S, J FROKIAER, D MARPLES, TH KWON, P AGRE \& M KNEPPER (2002) Aquaporins in the kidney: from molecules to medicine. Physiological Reviews 82: 205-244.

SCHMIDT-NIELSEN K (1979) Desert animals, physiological problems of heat and water. Dover Publishers, New York, USA. 277 pp.

SCHMIDT-NIELSEN B \& K SCHMIDT-NIELSEN (1951) Pulmonary water in desert rodents. American Journal of Physiology 162: 31-36.

VIO CP, C CESPEDES, P GALLARDO \& JL MASFERRER (1997) Renal identification of cyclooxigenase-2 in a subset of thick ascending limb cells. Hypertension 30:687-692.

WALSBERG G (2000) Small mammals in hot deserts: some generalizations revisited. Bioscience 50: 109120 . 